\title{
Phase Equilibrium Relations in the Systems Titania-Niobia and Zirconia-Niobia
}

\author{
R. S. Roth and L. W. Coughanour
}

\begin{abstract}
The systems $\mathrm{TiO}_{2}-\mathrm{Nb}_{2} \mathrm{O}_{5}$ and $\mathrm{ZrO}_{2}-\mathrm{Nb}_{2} \mathrm{O}_{5}$ were studied by means of solid-state reactions and by observation of fusion characteristics. Two binary compounds, $\mathrm{TiO}_{2} \cdot \mathrm{Nb}_{2} \mathrm{O}_{5}$ and $\mathrm{TiO}_{2} \cdot 3 \mathrm{Nb}_{2} \mathrm{O}_{5}$, were found to exist in the $\mathrm{TiO}_{2}-\mathrm{Nb}_{2} \mathrm{O}_{5}$ system. One compound, $6 \mathrm{ZrO}_{2} \cdot \mathrm{Nb}_{2} \mathrm{O}_{5}$, was found to exist in the $\mathrm{ZrO}_{2}-\mathrm{Nb}_{2} \mathrm{O}_{5}$ system. This compound has been found to be essentially isostructural with $\mathrm{ZrO}_{2} \cdot \mathrm{TiO}_{2}$ and has orthorhombic symmetry with the following unit cell parameters when quenched from $1,550^{\circ} \mathrm{C}: a=4.964 \mathrm{~A}, b=5.120 \mathrm{~A}, c=5.289 \mathrm{~A}$. Solid-solution formation was observed in both systems. A probable equilibrium diagram is presented for each system.
\end{abstract}

\section{Introduction}

A study of phase relationships in the systems $\mathrm{TiO}_{2}-\mathrm{Nb}_{2} \mathrm{O}_{5}$ and $\mathrm{ZrO}_{2}-\mathrm{Nb}_{2} \mathrm{O}_{5}$ has been conducted as a part of a program of fundamental studies of ceramic dielectrics. ${ }^{1}$ Some data for these systems have been reported by Durbin and Harman $[1]^{2}$ and Durbin, Wagner, and Harman [2], although no phase diagrams were presented for either system.

X-ray diffraction data, together with the determination of the melting points of the compounds and of the solidus and liquidus temperatures at various compositions across the two systems, have supplied data from which equilibrium diagrams have been constructed. The phase equilibrium studies were of a preliminary nature, in an attempt to locate ceramic bodies of improved dielectric properties; consequently the conclusions should only be considered as tentative.

\section{Sample Preparation and Test Methods}

The following starting materials were used in the preparation of samples:

$\mathrm{ZrO}_{2}$-Dense $\mathrm{ZrO}_{2}$, nominal 99 percent purity, obtained from the Titanium Alloy Manufacturing Co.

$\mathrm{TiO}_{2}$ - Highly purified titania, over 99.9 percent, obtained from the Titanium Division of the National Lead Co.

$\mathrm{Nb}_{2} \mathrm{O}_{5}$ - High-purity grade niobia, over 99.7 percent, obtained from the Fansteel Metallurgical Corp. The major impurity consisted of $\mathrm{Ta}_{2} \mathrm{O}_{5}$.

Calculations of weight composition were made to \pm 0.01 percent, no correction being made for the percentage purity of the raw materials.

The starting materials, in sufficient quantities to give a $10-\mathrm{g}$ sample, were weighed to the nearest milligram. They were then mixed together with a binder of a 5-percent soluble-starch solution, and formed into 1-in.-diam disks at a pressure of 5,000

1 This study was sponsored by the Office of Ordnance Research, Departmen of the Army.

2 Figures in brackets indicate literature references at the end of this paper. $\mathrm{lb} /$ in. $^{2}$ The pressed disks were fired for $4 \mathrm{hr}$ at $1,100^{\circ} \mathrm{C}$ on platinum foil in an air atmosphere, using an electrically-heated furnace wound with 80 percent $\mathrm{Pt}-20$ percent $\mathrm{Rh}$ wire.

Following the preliminary heat treatment, the disks were ground, remixed with starch-solution binder, and new disks about $1 / 4$ in. high were formed at $15,000 \mathrm{lb} /$ in. $^{2}$ in a $1 / 2$-in.-diam mold. Some of these disks were used for X-ray and petrographic studies, while others were used for the study of solidus and liquidus determinations. Those specimens selected for the X-ray study were refired at a temperature varying from $1,350^{\circ}$ to $1,550^{\circ} \mathrm{C}$ for a time period of from 4 to $24 \mathrm{hr}$, in order to insure equilibrium conditions. X-ray powder diffraction patterns were made using a high-angle recording spectrometer and $\mathrm{CuK} \alpha$ radiation.

Specimens for solidus and liquidus determinations were ground in the form of small four-sided pyramids, grooved on each side, as described by Geller, et al. [3]. Tests at temperatures below $1,525^{\circ}$ were made in the electrically heated furnace, using a Pt versus 90 $\mathrm{Pt}-10 \mathrm{Rh}$ thermocouple for temperature measurements. The tests at temperatures above $1,525^{\circ}$ were conducted in a thoria-resistor type furnace [4, 5]. The specimens rested on a disk of a platinumrhodium alloy, which was on a support of $\mathrm{ThO}_{2}$. The heating rate during the tests was about $4 \mathrm{deg}$ $\mathrm{C} / \mathrm{min}$ until the solidus temperature was approached, at which point it was reduced to about $2 \mathrm{deg} \mathrm{C} / \mathrm{min}$, or less. An oxidizing atmosphere existed in the furnace at all times. The temperature and fusion characteristics of the specimens were observed with an optical pyrometer calibrated by the Pyrometry Section of the Bureau. The solidus temperature was recorded as the first sign of liquid formation, as observed by rounding of the corners of the test pyramid. The temperature of complete melting, as observed by the formation of a flat button, was recorded as the liquidus temperature. In every case, several tests had to be made to determine these two values. The solidus and liquidus temperatures were arrived at by observations through the optical pyrometer and by visual inspection of the cooled specimen. 
The method of determination of such temperatures is subject to a number of sources of error. Among these are the slight deviations from blackbody conditions, the introduction of small quantities of impurities into the specimens in the forming and grinding operations, the possibility of reduction of $\mathrm{TiO}_{2}$ and $\mathrm{Nb}_{2} \mathrm{O}_{5}$ at high temperatures, and the inherent difficulty in the visual determination of the solidus and liquidus temperatures. It is believed that the temperatures as recorded are accurate to $\pm 10^{\circ} \mathrm{C}$.

\section{The $\mathrm{TiO}_{2}-\mathrm{Nb}_{2} \mathrm{O}_{5}$ System}

Brauer [6] reported three polymorphic forms of $\mathrm{Nb}_{2} \mathrm{O}_{5}$. The $\mathrm{H}$-form, or high-temperature form, was reported as stable at temperatures above $1,200^{\circ}$ to $1,250^{\circ} \mathrm{C}$. In this study wherever free $\mathrm{Nb}_{2} \mathrm{O}_{5}$ was found, the high-temperature form was the one observed in the heated specimens, although the lowtemperature form was used as the starting material.
Durbin and Harman [1] reported some fusion data for the system $\mathrm{TiO}_{2}-\mathrm{Nb}_{2} \mathrm{O}_{5}$. All of the compositions between $1: 4$ and $4: 1$ were shown to begin melting between $1,440^{\circ}$ and $1,500^{\circ} \mathrm{C}$. One compound, $\mathrm{TiO}_{2} \cdot \mathrm{Nb}_{2} \mathrm{O}_{5}$, was observed. Durbin, Wagner, and Harman [2] reported that X-ray examination showed $\mathrm{TiO}_{2}: \mathrm{Nb}_{2} \mathrm{O}_{5}$ to be a compound while $2 \mathrm{TiO}_{2}: \mathrm{Nb}_{2} \mathrm{O}_{5}$ was a mixture containing rutile.

Petrographic analyses in the present study were not relied upon, as all of the phases containing at least 50 percent $\mathrm{Nb}_{2} \mathrm{O}_{5}$ appeared very similar under the microscope. However, X-ray analyses succeeded in differentiating two compounds in the system $\mathrm{TiO}_{2}-\mathrm{Nb}_{2} \mathrm{O}_{5}$. Figure 1 is a graphical representation of the X-ray diagrams for values of $2 \theta$ between $16^{\circ}$ and $49^{\circ}$ for compositions of the following molecular ratios: $\mathrm{Nb}_{2} \mathrm{O}_{5}, \mathrm{TiO}_{2}: 9 \mathrm{Nb}_{2} \mathrm{O}_{5}, \mathrm{TiO}_{2}: 4 \mathrm{Nb}_{2} \mathrm{O}_{5}$, $\mathrm{TiO}_{2}: 3 \mathrm{Nb}_{2} \mathrm{O}_{5}, \quad \mathrm{TiO}_{2}: 2 \mathrm{Nb}_{2} \mathrm{O}_{5}, \quad 2 \mathrm{TiO}_{2}: 3 \mathrm{Nb}_{2} \mathrm{O}_{5}, \quad$ and $\mathrm{TiO}_{2}: \mathrm{Nb}_{2} \mathrm{O}_{5}$. These compositions were heated at either $1,350^{\circ}$ or $1,400^{\circ} \mathrm{C}$ for $3 \mathrm{hr}$ and quenched

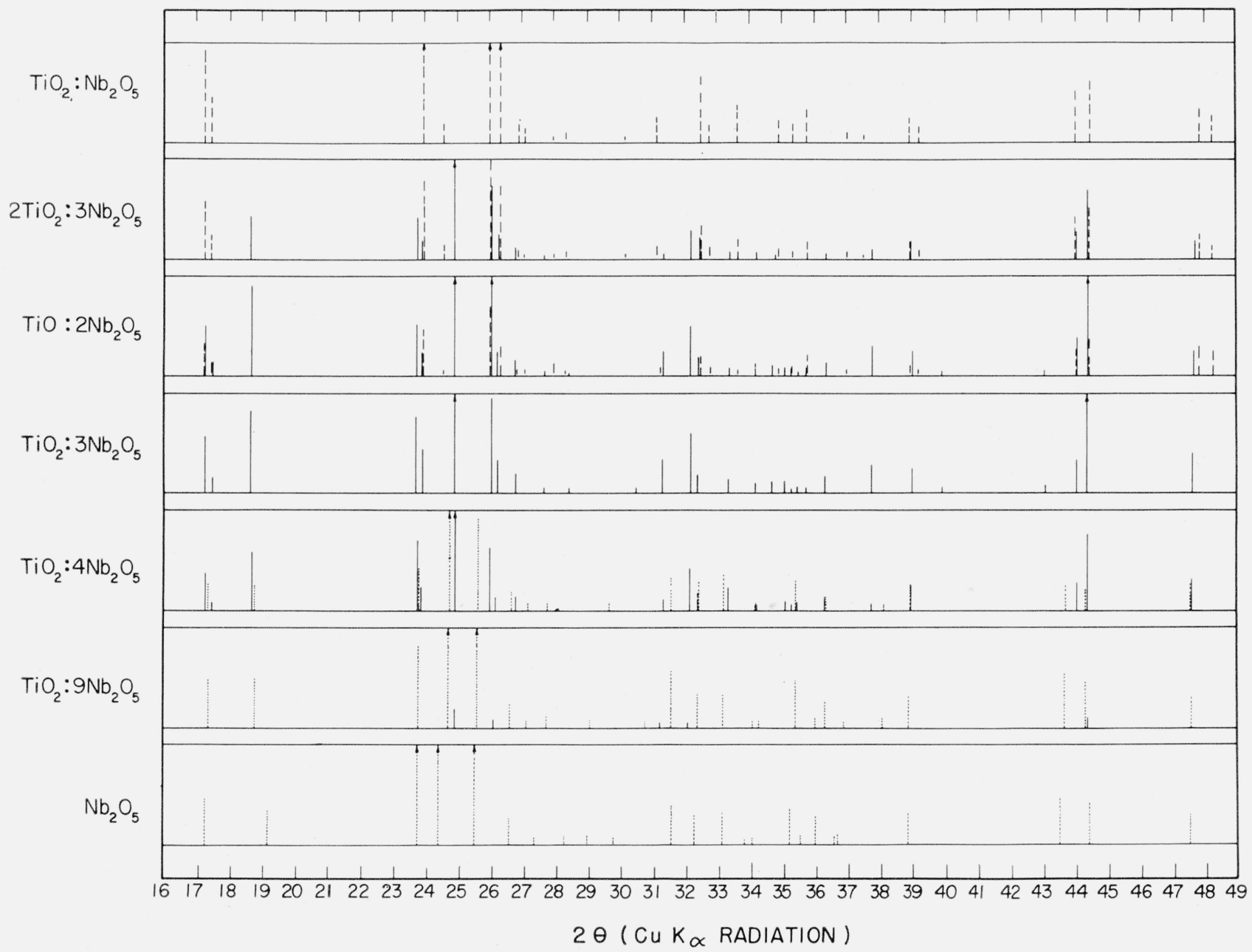

Figure 1. Graphical representation of the X-ray powder diffraction patterns for the compositions $\mathrm{Nb}_{2} \mathrm{O}_{5}, \mathrm{TiO}_{2}: 9 \mathrm{Nb}_{2} \mathrm{O}_{5}, \mathrm{TiO}_{2}$ : $4 \mathrm{Nb}_{2} \mathrm{O}_{5}, \mathrm{TiO}_{2}: 3 \mathrm{Nb}_{2} \mathrm{O}_{5}, \mathrm{TiO}_{2}: 2 \mathrm{Nb}_{2} \mathrm{O}_{5}, 2 \mathrm{TiO}_{2}: 3 \mathrm{Nb}_{2} \mathrm{O}_{5}$, and $\mathrm{TiO}_{2}: \mathrm{Nb}_{2} \mathrm{O}_{5}$ from $16^{\circ} 2 \theta$ to $49^{\circ} 2 \theta$.

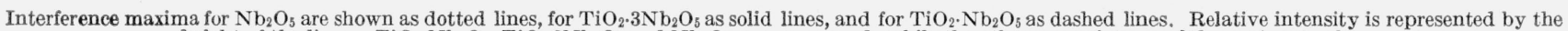
height of the lines. $\mathrm{TiO}_{2} \cdot \mathrm{Nb}_{2} \mathrm{O}_{5}, \mathrm{TiO}_{2} \cdot 3 \mathrm{Nb}_{2} \mathrm{O}_{5}$ and $\mathrm{Nb}_{2} \mathrm{O}_{5}$ are compounds while the others are mixtures of the conjugate phases. 
in air. Although there are many overlapping lines in the diffraction pattern, it can be seen that $\mathrm{TiO}_{2}: 3 \mathrm{Nb}_{2} \mathrm{O}_{5}$ and $\mathrm{TiO}_{2}: \mathrm{Nb}_{2} \mathrm{O}_{5}$ are probably pure compounds, while the other diagrams are mixtures of the two conjugate phases. The X-ray diffraction data for $\mathrm{TiO}_{2} \cdot \mathrm{Nb}_{2} \mathrm{O}_{5}$ and $\mathrm{TiO}_{2} \cdot 3 \mathrm{NbO}_{5}$ are given in tables 1 and 2 . It is possible that the compound designated $\mathrm{TiO}_{2} \cdot 3 \mathrm{Nb}_{2} \mathrm{O}_{5}$ may actually be intermediate in composition between $\mathrm{TiO}_{2}: 3 \mathrm{Nb}_{2} \mathrm{O}_{5}$ and

TABLE 1. X-ray powder diffraction data for the compound $\mathrm{TiO}_{2} \cdot \mathrm{Nb}_{2} \mathrm{O}_{5}$, furnace cooled from $1,400^{\circ} \mathrm{C}$

( $\mathrm{CuK} \alpha_{1}$ radiation)

\begin{tabular}{|c|c|c|c|c|c|}
\hline$d$ & R. I. ${ }^{a}$ & $d$ & R. I.a & $d$ & R. I. ${ }^{a}$ \\
\hline$A$ & & $A$ & & $A$ & \\
\hline 10. 2 & 19 & 1. 884 & 18 & 1. 270 & 14 \\
\hline 9.4 & 16 & 1. 849 & 7 & & \\
\hline 5.13 & 65 & 1.778 & 6 & 1. 267 & 13 \\
\hline 5.06 & 43 & & & 1. 264 & 10 \\
\hline \multirow[t]{2}{*}{3.71} & $100++b$ & 1. 760 & 9 & 1. 224 & 6 \\
\hline & & 1. 740 & 9 & 1. 216 & 9 \\
\hline 3. 61 & 18 & 1. 722 & 13 & 1. 208 & 7 \\
\hline 3.42 & $100+++b$ & 1. 712 & 9 & & \\
\hline $\begin{array}{l}3.38 \\
3.31\end{array}$ & $\begin{array}{c}100+b \\
22\end{array}$ & 1. 698 & 9 & $\begin{array}{l}\text { 1. } 143 \\
\text { 1. } 112\end{array}$ & $\begin{array}{l}4 \\
8\end{array}$ \\
\hline \multirow{2}{*}{ 3. 28} & 17 & 1. 662 & 43 & 1. 085 & 8 \\
\hline & & 1. 652 & 11 & 1. 064 & 5 \\
\hline 3.14 & 6 & 1. 622 & 10 & 1. 057 & 5 \\
\hline 2.95 & 7 & 1.579 & 8 & & \\
\hline 2.87 & 23 & & & 1. 049 & 7 \\
\hline 2.75 & 53 & 1.566 & 9 & 1. 035 & 5 \\
\hline \multirow[t]{2}{*}{ 2. 73} & 14 & 1. 556 & 14 & 1. 017 & 4 \\
\hline & & 1. 545 & 13 & 0.9993 & 8 \\
\hline 2.65 & 25 & 1.528 & 6 & .9502 & 17 \\
\hline 2.57 & 15 & 1.518 & 18 & & \\
\hline 2. 54 & 13 & & & .9476 & 14 \\
\hline \multirow[t]{2}{*}{2.51} & 22 & 1.475 & 6 & .9393 & 6 \\
\hline & & 1. 469 & 12 & .9298 & 12 \\
\hline 2.42 & 17 & 1. 456 & 9 & 9209 & 6 \\
\hline 2. 39 & 16 & 1.438 & 7 & .9127 & 4 \\
\hline 2. 31 & 18 & 1. 395 & 15 & & \\
\hline 2. 29 & 12 & & & .8536 & 4 \\
\hline \multirow{2}{*}{ 2. 055} & 42 & 1. 389 & 17 & 8279 & 12 \\
\hline & & 1. 291 & 4 & .8019 & 11 \\
\hline 2.035 & 48 & 1. 285 & 9 & - & \\
\hline 1. 899 & 26 & 1. 272 & 13 & & \\
\hline
\end{tabular}

a Relative intensity of diffraction peaks.

b These peaks were too strong to be completely recorded on the chart.

TABLE 2. X-ray powder diffraction data for the compound $\mathrm{TiO}_{2} \cdot 3 \mathrm{Nb}_{2} \mathrm{O}_{5}$, quenched from $1,400^{\circ} \mathrm{C}$

( $\mathrm{CuK} \alpha_{1}$ radiation)

\begin{tabular}{|c|c|c|c|}
\hline$d$ & R. I. ${ }^{a}$ & $d$ & R. I. \\
\hline$A$ & & A & \\
\hline 14.2 & 14 & 2. 090 & 5 \\
\hline 9. 6 & 29 & 2. 053 & 29 \\
\hline 7. 2 & 18 & 2. 039 & $100+$ \\
\hline 5. 13 & 43 & 1.907 & 31 \\
\hline 4. 75 & 70 & 1. 785 & 21 \\
\hline 3. 75 & 68 & 1. 752 & 11 \\
\hline 3. 71 & 42 & 1. 697 & 10 \\
\hline 3. 57 & $100++b$ & 1. 682 & 15 \\
\hline 3. 42 & 82 & 1. 677 & 29 \\
\hline 3. 33 & 19 & 1. 663 & 25 \\
\hline 2.85 & 29 & 1. 574 & 22 \\
\hline 2. 78 & 49 & 1. 551 & 9 \\
\hline 2. 68 & 10 & 1. 448 & 8 \\
\hline 2. 62 & 8 & 1. 398 & 8 \\
\hline 2. 58 & 9 & 1. 394 & 9 \\
\hline 2.56 & 9 & 1. 298 & 36 \\
\hline 2.47 & 11 & 1.135 & 21 \\
\hline 2. 38 & 25 & 1. 051 & 11 \\
\hline 2. 30 & 22 & & \\
\hline
\end{tabular}

a Relative intensity of diffraction peaks.

b These peaks were too strong to be completely recorded on the chart.
$\mathrm{TiO}_{2}: 2 \mathrm{Nb}_{2} \mathrm{O}_{5}$; however, the simple ratio of $1: 3$ is taken as the most logical composition for this compound.

The fusion-behavior data from which the equilibrium diagram is constructed are given in table 3, and the diagram is shown in figure 2. It may be seen that the compound $\mathrm{TiO}_{2} \cdot \mathrm{Nb}_{2} \mathrm{O}_{5}$ melts congruently at about $1,490^{\circ} \mathrm{C}$ and the compound $\mathrm{TiO}_{2}$. $3 \mathrm{Nb}_{2} \mathrm{O}_{5}$ melts congruently at about $1,480{ }^{\circ} \mathrm{C}$. At the eutectic temperature, $1,467^{\circ} \mathrm{C}$ and 21 mole percent $\mathrm{TiO}_{2}, 12$ to 13 mole percent $\mathrm{TiO}_{2}$ is accepted into solid solution by $\mathrm{Nb}_{2} \mathrm{O}_{5}$. At the eutectic temperature, $1,475^{\circ} \mathrm{C}$ and 58 mole percent $\mathrm{TiO}_{2}$, about 17 mole percent $\mathrm{Nb}_{2} \mathrm{O}_{5}$ is found in solid solution in $\mathrm{TiO}_{2}$. Both of the solid solutions decrease to slightly less than 10 percent at room temperature. The

TABLE 3. Fusion characteristics of compositions in the $\mathrm{TiO}_{2}-\mathrm{Nb}_{2} \mathrm{O}_{5}$ system

\begin{tabular}{|c|c|c|c|c|}
\hline \multicolumn{2}{|c|}{$\begin{array}{l}\text { Composition mole } \\
\text { percent }\end{array}$} & \multicolumn{2}{|c|}{$\begin{array}{l}\text { Temperature } \\
\text { observed }\end{array}$} & \multirow{2}{*}{$\begin{array}{c}\text { X-ray examination of quenched } \\
\text { samples a }\end{array}$} \\
\hline $\mathrm{TiO}_{2}$ & $\mathrm{Nb}_{2} \mathrm{O}_{5}$ & Solidus & Liquidus & \\
\hline$\%$ & $\%$ & ${ }^{\circ} \mathrm{C}$ & ${ }^{\circ} \mathrm{C}$ & \\
\hline $\begin{array}{l}95 \\
90\end{array}$ & $\begin{array}{r}5 \\
10\end{array}$ & $\begin{array}{l}1,780 \\
1,510\end{array}$ & 1,800 & \\
\hline 85.71 & 14. 29 & 1,490 & -..... & \\
\hline 80 & 20 & 1,475 & ........ & $\begin{array}{l}\mathrm{TiO}_{2} \cdot \mathrm{Nb}_{2} \mathrm{O}_{5}+\mathrm{TiO}_{2} \text { solid solu- } \\
\text { tion. }\end{array}$ \\
\hline 75 & 25 & 1,475 & n... & \\
\hline 67 & 33 & 1,475 & 1,500 & Do. \\
\hline $\begin{array}{l}60 \\
50\end{array}$ & $\begin{array}{l}40 \\
50\end{array}$ & $\begin{array}{l}1,470 \\
1,490\end{array}$ & $\begin{array}{l}1,480 \\
1,490\end{array}$ & $\mathrm{TiO}_{2} \cdot \mathrm{Nb}_{2} \mathrm{O}_{3}$ \\
\hline 40 & 60 & 1,465 & 1,470 & $\mathrm{TiO}_{2} \cdot 3 \mathrm{Nb}_{2} \mathrm{O}_{5}+\mathrm{TiO}_{2} \cdot \mathrm{Nb}_{2} \mathrm{O}_{5}$ \\
\hline 33 & 67 & 1,465 & 1,475 & Do. \\
\hline 25 & 75 & 1,480 & 1,480 & $\mathrm{TiO}_{2} \cdot 3 \mathrm{Nb}_{2} \mathrm{O}_{5}$ \\
\hline 20 & 80 & 1,465 & 1,470 & $\mathrm{Nb}_{3} \mathrm{O}_{5}$ solid solution+ $+\mathrm{TiO}_{2}$. \\
\hline 16. 67 & 83. 33 & -...... & 1,475 & \\
\hline $\begin{array}{l}14.29 \\
10\end{array}$ & $\begin{array}{l}85.71 \\
90\end{array}$ & 1,475 & 1,485 & 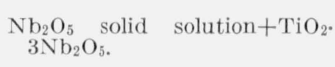 \\
\hline 5 & 95 & 1,485 & 1,495 & \\
\hline 0 & 100 & 1,500 & 1,500 & $\mathrm{Nb}_{2} \mathrm{O}_{5}$ \\
\hline
\end{tabular}

a Specimens for X-ray analyses were quenched, but compounds found may not have been those present at quenching temperature.

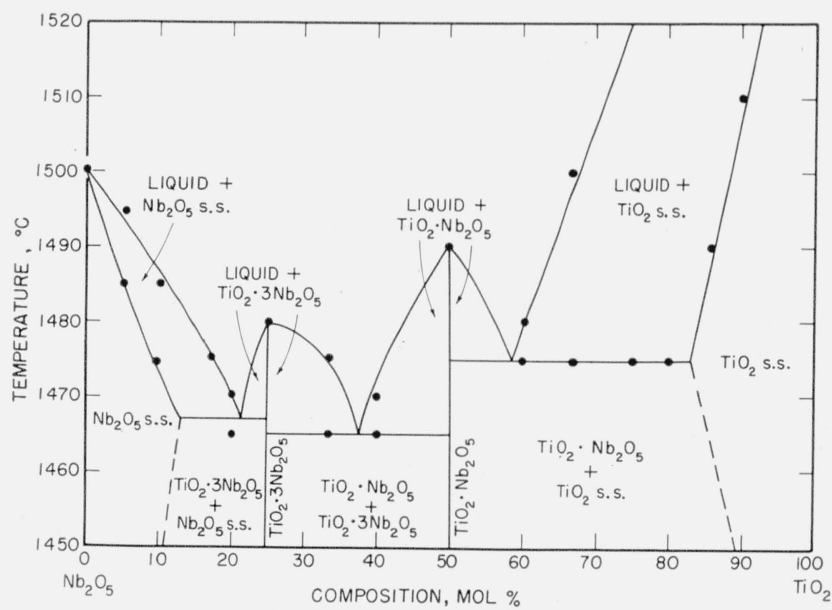

Figure 2. Suggested equilibrium diagram for the system $\mathrm{TiO}_{2}-\mathrm{Nb}_{2} \mathrm{O}_{5}$.

(s. s. = solid solution) 
eutectic between the two binary compounds occurs about 38 mole percent $\mathrm{TiO}_{2}$ and $1,465^{\circ} \mathrm{C}$. Neither of the two binary compounds shows solid solution.

\section{The $\mathrm{ZrO}_{2}-\mathrm{Nb}_{2} \mathrm{O}_{5}$ System}

Durbin and Harman [1] reported some fusion data for the system $\mathrm{ZrO}_{2}-\mathrm{Nb}_{2} \mathrm{O}_{5}$. Compositions high in $\mathrm{Nb}_{2} \mathrm{O}_{5}$ were reported as melting between about $1,400^{\circ}$ and $1,450^{\circ} \mathrm{C}$ while mixtures higher in $\mathrm{ZrO}_{2}$ melted between $1,450^{\circ}$ and $1,550^{\circ} \mathrm{C}$. Durbin, Wagner, and Harman [2] found solid solution of $\mathrm{ZrO}_{2}$ in $\mathrm{Nb}_{2} \mathrm{O}_{5}$. These authors claimed that X-ray diffraction showed that cubic $\mathrm{ZrO}_{2}$ was stabilized, indicating solid solution of $\mathrm{Nb}_{2} \mathrm{O}_{5}$ in $\mathrm{ZrO}_{2}$. They report no compounds in this system.

In the present study, X-ray analyses have indicated the presence of a new compound, $6 \mathrm{ZrO}_{2} \cdot \mathrm{Nb}_{2} \mathrm{O}_{5}$, in the system $\mathrm{ZrO}_{2}-\mathrm{Nb}_{2} \mathrm{O}_{5}$. The $\mathrm{X}$-ray pattern is very similar, both in $d$ values and relative intensities, to that of the compound $\mathrm{ZrO}_{2} \cdot \mathrm{TiO}_{2}$ [7]. The similarity between the compounds becomes apparent if the composition of the compound $6 \mathrm{ZrO}_{2} \cdot \mathrm{Nb}_{2} \mathrm{O}_{5}$ is written as $\mathrm{Zr}_{4}\left(\mathrm{Nb}_{2}, \mathrm{Zr}_{2}\right) \mathrm{O}_{16} \mathrm{O}$ and compared with $4 \mathrm{ZrTiO}_{4}$ or $\mathrm{Zr}_{4} \mathrm{Ti}_{4} \mathrm{O}_{16}$. It seems possible that the structural arrangement of this compound may be capable of accommodating an additional one-fourth of an oxygen ion per formula unit. Because of the similarity of $\mathrm{Nb}_{2} \mathrm{O}_{5}$ and $\mathrm{Ta}_{2} \mathrm{O}_{5}$, a specimen of $6 \mathrm{ZrO}$. $\mathrm{Ta}_{2} \mathrm{O}_{5}$ was prepared and studied by X-ray diffraction. This composition proved to be isostructural with $6 \mathrm{ZrO}_{2} \cdot \mathrm{Nb}_{2} \mathrm{O}_{5}$ and $\mathrm{ZrO}_{2} \cdot \mathrm{TiO}_{2}$. All three compounds are orthorhombic with unit cell parameters as shown in table 4. The X-ray powder diagram for the compound $6 \mathrm{ZrO}_{2} \cdot \mathrm{Nb}_{2} \mathrm{O}_{5}$ is given in table 5. Another possible interpretation of the structure occurring at the composition $6 \mathrm{ZrO}_{2} \cdot \mathrm{Nb}_{2} \mathrm{O}_{5}$ is that of a solid solution of $\mathrm{ZrO}_{2}$. This would be similar to the case of the cubic $\mathrm{ZrO}_{2}$ solid solutions in the systems involving $\mathrm{ZrO}_{2}$ and oxides of divalent ions like $\mathrm{CaO}$, $\mathrm{MgO}, \mathrm{MnO}$, and $\mathrm{TiO}$. However, the identity of $\mathrm{ZrO}_{2} \cdot \mathrm{TiO}_{2}$ as a compound seems to be fully established $[7,8]$. The similarity of the structures of the two compositions justifies the assumption of $6 \mathrm{ZrO}_{2}$. $\mathrm{Nb}_{2} \mathrm{O}_{5}$ as a true compound. Apparently the cubic $\mathrm{ZrO}_{2}$ solid solution reported by Durbin, et al. [2] in this system was actually the compound $6 \mathrm{ZrO}_{2} \cdot \mathrm{Nb}_{2} \mathrm{O}_{5}$. Their interpretation may be explained by the fact that the strongest diffraction lines for the compound are close to what would be expected for a cubic $\mathrm{ZrO}_{2}$ solid solution.

The equilibrium diagram for the $\mathrm{ZrO}_{2}-\mathrm{Nb}_{2} \mathrm{O}_{5}$ system, as determined from the present study, is shown in figure 3 and the fusion-behavior data from

TABLE 4. Unit cell parameters for the isostructural compounds, $\mathrm{ZrO}_{2} \cdot \mathrm{TiO}_{2}, 6 \mathrm{ZrO}_{2} \cdot \mathrm{Nb}_{2} \mathrm{O}_{5}$, and $6 \mathrm{ZrO}_{2} \cdot \mathrm{Ta}_{2} \mathrm{O}_{5}$

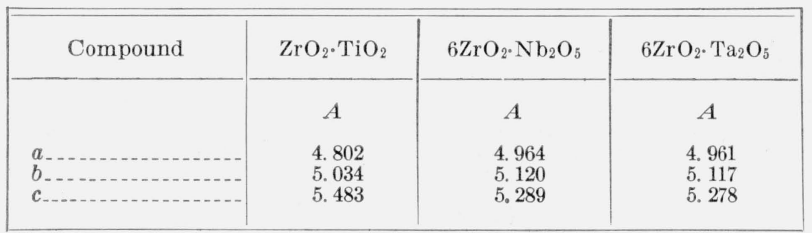

TABLE 5. X-ray powder diffraction data for the compound $6 \mathrm{ZrO}_{2} \cdot \mathrm{Nb}_{2} \mathrm{O}_{5}$, quenched from $1,550^{\circ} \mathrm{C}$

\begin{tabular}{|c|c|c|c|c|c|}
\hline$d$ & $h k l$ & R. I. a & $d$ & $h k l$ & R. I. ${ }^{a}$ \\
\hline $\begin{array}{c}\mathrm{A} \\
4.92 \\
3.61 \\
2.95 \\
2.64 \\
2.56\end{array}$ & $\begin{array}{l}100(?) \\
101 \\
111 \\
002 \\
020\end{array}$ & $\begin{array}{r}1 \\
9 \\
100 \\
17 \\
18\end{array}$ & $\begin{array}{l}\mathrm{A} \\
\text { 1. } 138 \\
1.125 \\
1.118 \\
1.098 \\
1.092\end{array}$ & $\begin{array}{l} \\
-\end{array}$ & $\begin{array}{l}9 \\
2 \\
3 \\
3 \\
4\end{array}$ \\
\hline $\begin{array}{l}2.48 \\
2.35 \\
2.31 \\
2.244 \\
2.179\end{array}$ & $\begin{array}{c}200 \\
012 \\
021 \\
201 / 210 \\
112\end{array}$ & $\begin{array}{r}12 \\
6 \\
2 \\
1 \\
1\end{array}$ & $\begin{array}{l}\text { 1. } 062 \\
\text { 1. } 046 \\
\text { 1. } 034 \\
\text { 1. } 030 \\
1.014\end{array}$ & $\begin{array}{c} \\
\cdots \\
-\cdots\end{array}$ & $\begin{array}{l}3 \\
6 \\
3 \\
4 \\
3\end{array}$ \\
\hline $\begin{array}{l}2.091 \\
2.020 \\
1.838 \\
1.809 \\
1.782\end{array}$ & $\begin{array}{l}121 \\
211 \\
022 \\
202 \\
220\end{array}$ & $\begin{array}{r}6 \\
3 \\
23 \\
21 \\
28\end{array}$ & $\begin{array}{r}0.9856 \\
.9634 \\
.9589 \\
.9197 \\
.8914\end{array}$ & 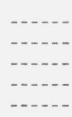 & $\begin{array}{l}7 \\
3 \\
6 \\
1 \\
7\end{array}$ \\
\hline $\begin{array}{l}1.706 \\
1.660 \\
1.579 \\
1.545 \\
1.511\end{array}$ & $\begin{array}{l}212 \\
103 \\
113 \\
131 \\
311\end{array}$ & $\begin{array}{l}10 \\
11 \\
19 \\
22 \\
18\end{array}$ & $\begin{array}{l}.8783 \\
.8719 \\
.8681 \\
.8657 \\
.8600\end{array}$ & 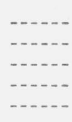 & $\begin{array}{l}2 \\
2 \\
3 \\
3 \\
3\end{array}$ \\
\hline $\begin{array}{l}1.478 \\
1.456 \\
1.435 \\
1.393 \\
1.321\end{array}$ & $\begin{array}{l}222 \\
023 \\
032 \\
123 \\
004\end{array}$ & $\begin{array}{r}14 \\
1 \\
3 \\
7 \\
2\end{array}$ & $\begin{array}{l}.8536 \\
.8480 \\
.8452 \\
.8416 \\
.8195\end{array}$ & 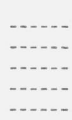 & $\begin{array}{l}3 \\
3 \\
3 \\
4 \\
5\end{array}$ \\
\hline $\begin{array}{l}\text { 1. } 281 \\
\text { 1. } 243 \\
\text { 1. } 207 \\
\text { 1. } 191 \\
\text { 1. } 175\end{array}$ & $\begin{array}{c}040 / 014 \\
400 \\
-0\end{array}$ & $\begin{array}{l}7 \\
4 \\
3 \\
6 \\
6\end{array}$ & $\begin{array}{l}.8122 \\
.8074 \\
.8046 \\
.7998 \\
.7902\end{array}$ & 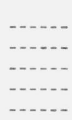 & $\begin{array}{l}1 \\
2 \\
3 \\
2 \\
2\end{array}$ \\
\hline $\begin{array}{l}\text { 1. } 167 \\
\text { 1. } 160 \\
1.153\end{array}$ & - & $\begin{array}{l}3 \\
7 \\
3\end{array}$ & $\begin{array}{r}.7882 \\
.7827 \\
.7810\end{array}$ & - & $\begin{array}{l}1 \\
1 \\
3\end{array}$ \\
\hline
\end{tabular}

s R. I. is the intensity of each diffraction peak relative to the strongest peak.

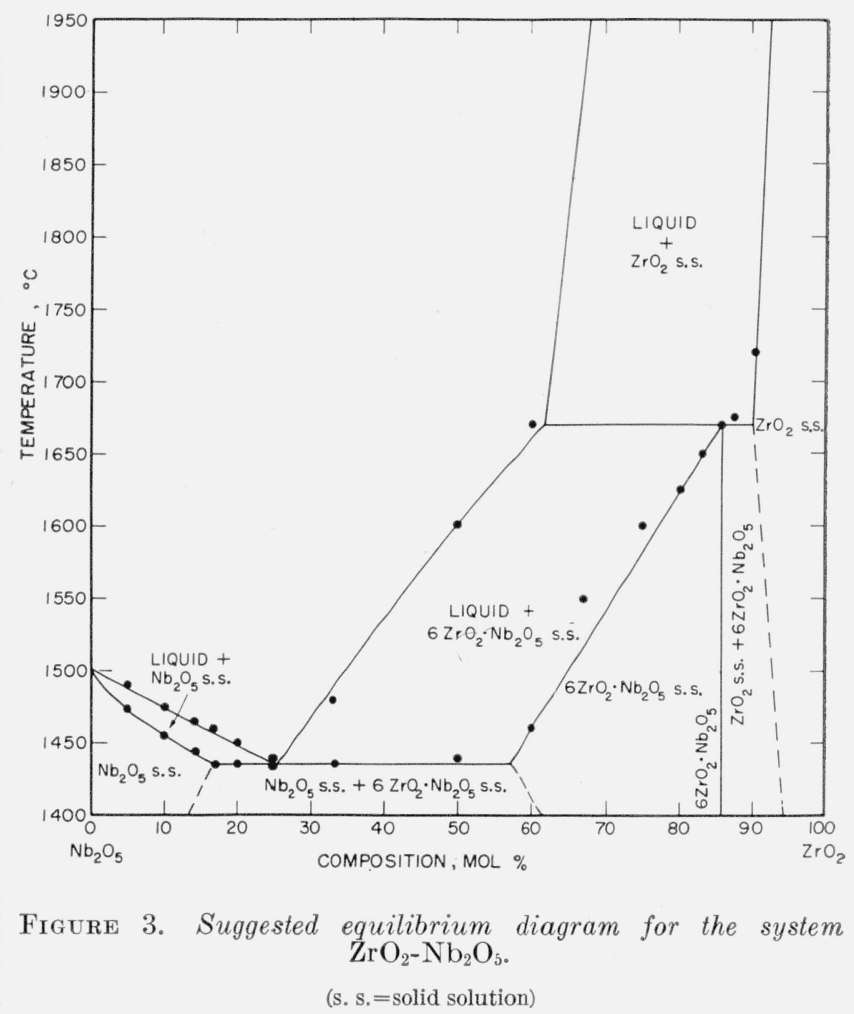


which the diagram was constructed are listed in table 6. It is seen that the compound $6 \mathrm{ZrO}_{2} \cdot \mathrm{Nb}_{2} \mathrm{O}_{5}$ melts incongruently at about $1,670^{\circ} \mathrm{C}$. The eutectic point for the system is located at about 25 mole percent $\mathrm{ZrO}_{2}$ and $1,435^{\circ} \mathrm{C}$. Rather extensive solidsolution formation is noted at the higher temperatures. $\mathrm{Nb}_{2} \mathrm{O}_{5}$ accepts about 16 percent $\mathrm{ZrO}_{2}$ into solid solution at the eutectic temperature, and there is considerable solid solution between the $6 \mathrm{ZrO}_{2} \cdot \mathrm{Nb}_{2} \mathrm{O}_{5}$ compound and $\mathrm{Nb}_{2} \mathrm{O}_{5}$. This solid solution is apparently not maintained by quenching, as X-ray patterns of compositions within this field show two phases. $\mathrm{ZrO}_{2}$ apparently also accepts a small amount of $\mathrm{Nb}_{2} \mathrm{O}_{5}$ in solid solution at the higher temperatures, but loses most of it on cooling.

TABLE 6. Fusion characteristics of compositions in the $\mathrm{ZrO}_{2}-\mathrm{Nb}_{2} \mathrm{O}_{5}$ system

\begin{tabular}{|c|c|c|c|c|}
\hline \multicolumn{2}{|c|}{$\begin{array}{l}\text { Composition mole } \\
\text { percent }\end{array}$} & \multicolumn{2}{|c|}{$\begin{array}{l}\text { Temperature } \\
\text { observed }\end{array}$} & \multirow{2}{*}{$\begin{array}{l}\text { X-ray examination of quenched } \\
\text { samples a }\end{array}$} \\
\hline $\mathrm{ZrO}_{2}$ & $\mathrm{Nb}_{2} \mathrm{O}_{5}$ & Solidus & Liquidus & \\
\hline $\begin{array}{l}\% \\
95 \\
90 \\
87.5 f_{j} \\
85.71 \\
83.33\end{array}$ & $\begin{array}{l}\% \\
5 \\
10 \\
12.50 \\
14.29 \\
16.67\end{array}$ & $\begin{array}{c}{ }^{\circ} \mathrm{C} \\
>1,850 \\
1,725 \\
1,675 \\
1,670 \\
1,650\end{array}$ & $\begin{array}{c}{ }^{\circ} \mathrm{C} \\
-{ }^{\prime}\end{array}$ & $\begin{array}{l}6 \mathrm{ZrO}_{2} \cdot \mathrm{Nb}_{2} \mathrm{O}_{5}+\text { monoclinic } \mathrm{ZrO}_{2} \\
\quad \mathrm{Do}^{2} \\
6 \mathrm{ZrO}_{2} \cdot \mathrm{Nb}_{2} \mathrm{O}_{5} . \\
6 \mathrm{ZrO}_{2} \cdot \mathrm{Nb}_{2} \mathrm{O}_{5} \text { solid solution. }\end{array}$ \\
\hline 80 & 20 & 1,625 & & \\
\hline 75 & $\begin{array}{l}25 \\
33\end{array}$ & $\begin{array}{l}1,600 \\
1,550\end{array}$ & (n) & $\mathrm{Nb}_{2} \mathrm{O}_{5}$ solid solution $+6 \mathrm{ZrO} 2$ \\
\hline 60 & 40 & 1,460 & 1,670 & $\mathrm{Nb}_{2} \mathrm{O}_{5}$ solid solution. \\
\hline 50 & 50 & 1,440 & 1,600 & $\begin{array}{l}\mathrm{Nb}_{2} \mathrm{O}_{5} \text { solid solution }+6 \mathrm{ZrO}_{2} \\
\mathrm{Nb}_{2} \mathrm{O}_{5} \text { solid solution. }\end{array}$ \\
\hline 40 & 60 & & & \multirow{7}{*}{$\begin{array}{l}\mathrm{Nb}_{2} \mathrm{O}_{5} \text { solid solution }+6 \mathrm{ZrO}_{2} . \\
\mathrm{Nb}_{2} \mathrm{O}_{5} \text { solid solution. } \\
\mathrm{Nb}_{2} \mathrm{O}_{5} \text { solid solution }+6 \mathrm{ZrO}_{2} . \\
\mathrm{Nb}_{2} \mathrm{O}_{5} \text { solid solution. }\end{array}$} \\
\hline 33 & 67 & 1,435 & 1,480 & \\
\hline $\begin{array}{l}25 \\
20\end{array}$ & $\begin{array}{l}75 \\
80\end{array}$ & $\begin{array}{l}1,435 \\
1,435\end{array}$ & $\begin{array}{l}1,440 \\
1,450\end{array}$ & \\
\hline 16.67 & 83. 33 & 1,435 & 1,460 & \\
\hline 14. 29 & 85. 71 & 1,445 & 1,465 & \\
\hline 10 & 90 & 1,455 & 1,475 & \\
\hline 5 & 95 & 1,475 & 1,490 & \\
\hline
\end{tabular}

a Specimens for X-ray analyses were quenched but compounds found may not have been those present at quenching temperature.

\section{Summary}

The systems $\mathrm{TiO}_{2}-\mathrm{Nb}_{2} \mathrm{O}_{5}$ and $\mathrm{ZrO}_{2}-\mathrm{Nb}_{2} \mathrm{O}_{5}$ were studied by means of solid-state reactions, fusion characteristics and X-ray diffraction data. The probable existence of two compounds in the $\mathrm{TiO}_{2}-$ $\mathrm{Nb}_{2} \mathrm{O}_{5}$ system was shown. They are $\mathrm{TiO}_{2} \cdot \mathrm{Nb}_{2} \mathrm{O}_{5}$ which melts congruently at about $1,490^{\circ} \mathrm{C}$. and $\mathrm{TiO}_{2} \cdot 3 \mathrm{Nb}_{2} \mathrm{O}_{5}$ which melts congruently at about $1,480^{\circ}$ C. The three eutectic points are located as follows: 21 mole percent $\mathrm{TiO}_{2}$ and $1,467^{\circ} \mathrm{C}$., about 38 mole percent $\mathrm{TiO}_{2}$ and $1,465^{\circ} \mathrm{C}$, and about 58 mole percent $\mathrm{TiO}_{2}$ and $1,475^{\circ}$ C. Partial solid-solution formation was noted in this system.

One compound, $6 \mathrm{ZrO}_{2} \cdot \mathrm{Nb}_{2} \mathrm{O}_{5}$, was found to occur in the $\mathrm{ZrO}_{2}-\mathrm{Nb}_{2} \mathrm{O}_{5}$ system. The compound is essentially isostructural with $\mathrm{ZrO}_{2} \cdot \mathrm{TiO}_{2}$ and melts incongruently at about $1,670^{\circ} \mathrm{C}$. The eutectic point for the system was located at about 25 mole percent $\mathrm{ZrO}_{2}$ and $1,435^{\circ} \mathrm{C}$. Extensive solid-solution formation was noted.

\section{References}

[1] E. A. Durbin and C. G. Harman, Battelle Memorial Inst. 791 (Dec. 15, 1952).

[2] E. A. Durbin, H. E. Wagner, and C. G. Harman, BMI792 (Dec. 15, 1952).

[3] R. F. Geller, P. J. Yavorskv, B. L. Steierman, and A. S. Creamer, J. Research NBS 36, 277 (1946) RP1703.

[4] R. F. Geller, J. Research NBS 27, 555 (1941) RP1443.

[5] S. M. Lang and R. F. Geller, J. Am. Ceram. Soc. 34, 193 (1951).

[6] G. Brauer, Z. anorg. u. allgem. Chem. 248, 1-31 (1941).

[7] L. W. Coughanour, R. S. Roth, and V. A. DeProsse, J. Research NBS 52, 37 (1954) RP2470.

[8] F. H. Brown and P. Duwez, J. Am. Ceram. Soc. 37, 129 (1954).

Washington, May 27, 1955. 